Article

\title{
Can Blended Finance Be a Game Changer in Sustainable Development? An Empirical Investigation of the "Lucas Paradox"
}

\author{
Hyojin Kim (1) and Hannah Jun *(1) \\ Graduate School of International Studies, Ewha Womans University, Seoul 03760, Korea; hyonala@gmail.com \\ * Correspondence: hannahjun@ewha.ac.kr
}

\begin{abstract}
In recent years, the global development community has been emphasizing blended finance approaches for economic development without taking into consideration practical implications of the Lucas Paradox, or the observation that capital does not flow from rich to poor countries. To prevent misuse of official development funds as catalysts for private flows, it is crucial to consider the direction of blended finance approaches in light of the Lucas Paradox. To fill this important gap in the literature, this paper investigates determinants of capital flows in recipient countries where a blended finance strategy is applied in light of the Lucas Paradox, with a focus on foreign direct investment and portfolio equity investment. For the analysis, this paper utilizes a cross-sectional sample of 157 countries between 2002 and 2018, including ODA recipients and OECD DAC members, by conducting a regression analysis based on the ordinary least squares (OLS). Our findings suggest that the Lucas Paradox strongly exists in all recipient countries that can utilize ODA as a catalyst, which is the core of the blended finance strategy. Institutional quality, human capital and asymmetric information improvement appear to mitigate the Lucas Paradox, although the paradox does not disappear entirely. In addition, total ODA, institutional and human capital appear to be determinants of the paradox in the multiple regression model.
\end{abstract}

Citation: Kim, H.; Jun, H. Can Blended Finance Be a Game Changer in Sustainable Development? An Empirical Investigation of the "Lucas Paradox". Sustainability 2022, 14, 2186. https://doi.org/10.3390/ su14042186

Academic Editor: Bruce Morley

Received: 7 December 2021

Accepted: 9 February 2022

Published: 15 February 2022

Publisher's Note: MDPI stays neutral with regard to jurisdictional claims in published maps and institutional affiliations.

Copyright: (C) 2022 by the authors. Licensee MDPI, Basel, Switzerland. This article is an open access article distributed under the terms and conditions of the Creative Commons Attribution (CC BY) license (https:/ / creativecommons.org/licenses/by/ $4.0 /)$.

Keywords: blended finance; foreign direct investment (FDI); Lucas Paradox; official development assistance (ODA); sustainable development

\section{Introduction}

While organizations such as the UK's CDC group (formerly the Commonwealth Development Corporation) and the International Finance Corporation (IFC) have emphasized the need to crowd in private investments to address global development challenges since the 1950s, the international community has generally responded to a lack of development funds by increasing the amount of official development assistance (ODA) on the basis of the 1969 Pearson Report [1]. However, estimates that suggest an additional USD 2.5 trillion is needed each year to achieve the ambitious Sustainable Development Goals (SDGs) in developing countries [2] and the reality of ODA limitations have led to a revisiting of the potential of private investment-specifically, that the private sector can help fill the growing financing gap in developing countries [3]. Indeed, while the 2015 Addis Ababa Action Agenda (AAAA) presented a global framework for financing sustainable development through an increase in ODA volume, mobilization of domestic public resources, international trade for development and management of debt sustainability, at the heart of the agenda was attracting private capital.

Given these trends, the international community has become more enthusiastic about the possibility of harnessing private capital for sustainable development $[4,5]$. In particular, there has been growing interest in a blended finance approach, which aims to strategically use official development finance to attract private capital through impact, returns and leverage [6]. Key instruments to achieve this objective include guarantees, syndicated 
loans, shares in collective investment vehicles (CIVs), direct investment in companies and credit lines. According to an OECD survey [7], the combination of these blended finance instruments led to the mobilization of USD 257.6 billion from the private sector via development finance intervention between 2012 and 2019. Furthermore, the OECD found that private investment with development purposes in developing countries increased steadily through blended finance, with mobilized private finance reaching USD 48.4 billion in 2018 or a $28 \%$ increase compared to 2017 [8], although it temporarily decreased by $9 \%$ in 2019 compared to 2018 [7]. As these data add fuel to the development finance narrative "from billions in ODA to trillions in investments of all kinds," it is clear why the development community is enthusiastic about expanding blended finance approaches.

At the same time, we have seen meaningful differences in the flows of private capital depending on a country's economic level. Importantly, the flow of private resources toward least-developed countries (LDCs) is relatively low vis-à-vis developing countries with larger economies [9]. This can be seen to support the existence of the Lucas Paradox, or the observation by Robert Lucas in 1990 that capital does not flow from rich to poor countries but is mostly invested in rich countries-a phenomenon still witnessed in today's free economic system $[10,11]$. Recent data also suggest that private investment toward developing countries is not as active compared to the capital markets of developed countries with the highest level of per capita income [4,12].

In this regard, it can be argued that the development community has been emphasizing blended finance approaches without taking into consideration practical implications of the Lucas Paradox. To prevent misuse of official development funds as catalysts for private flows, it is crucial to consider the direction of blended finance approaches in light of the Lucas Paradox. However, despite the urgency of critical analysis, there have been no studies in the academic literature that have diagnosed blended finance in consideration of the Lucas Paradox or those that have provided empirical reviews of how official development funds can be used to mitigate its effects, thus securing private flows. To fill this important gap in the literature, this paper aims to pinpoint determinants of the Lucas Paradox in recipient countries where a blended finance strategy is applied. In particular, this study will focus on foreign direct investment and portfolio equity investment that can stimulate economic and social development in developing countries [13-15], as private investment through a blended finance approach is mainly generated by traditional commercial investors [9].

Our paper is significant in that it identifies determinants of capital flows in recipient countries where a blended finance strategy is applied in light of the Lucas Paradox, which differ depending on the income level of the recipient countries and suggest a blended finance approach that takes this into account. In particular, the approach proposed by our study may contribute to development policies that have been striving to expand the flow of private resources through blended finance. In addition, it can contribute to filling the gap in related literature that attempts to identify determinants of the Lucas Paradox.

The rest of the paper is organized as follows. Section 2 presents a comprehensive overview of blended finance as a basis for this study and provides a critical review of existing literature on blended finance considering the Lucas Paradox. Section 3 addresses our research design. Section 4 presents key findings of the study and suggests future directions for blended finance based on the empirical review of what sectoral approach of ODA mitigates the Lucas Paradox. Concluding remarks are provided in Section 5.

Our findings suggest that the Lucas Paradox strongly exists in all recipient countries that can utilize ODA as a catalyst, which is the core of the blended finance strategy. Institutional quality, human capital and asymmetric information improvement appear to mitigate the Lucas Paradox, although the paradox does not disappear entirely. In addition, total ODA, institutional and human capital appear to be determinants of the paradox in the multiple regression model. 


\section{Literature Review}

\subsection{Why Blended Finance?}

A blended finance approach refers to a means of investment that encompasses a "strategic use of development finance to mobilize private capital to achieve development goals" [16]. This concept, which emerged within the development community in earnest at the beginning of the SDGs era, has at its core the channeling of private investment to sectors of high-development impact considering society, the environment and economy, while at the same time delivering risk-adjusted returns [17]. Within this framework, development finance has been described as "leverage" to drive private capital flows. In the 2015 Addis Ababa Conference, which officially discussed financing for development at a global level under the initiative of the United Nations (UN), blended finance was raised as a key measure to expand finance for the SDGs. As a result of the conference, the AAAA defined blended finance as "combining concessional public finance with non-concessional private finance." Going further, AAAA stated that in order to combine these two mutually opposed sources (public and private resources), concessional official resources (i.e., ODA) should be used as a catalyst to mobilize additional resources from other sources, including the public and private sectors. In this sense, ODA can help catalyze private flows by improving tax collection, strengthening the environment for revitalizing developing countries, building essential public services and mitigating risks.

However, while this approach has existed since the Marshall Plan in 1948 [17], the development community's interest in expanding development funding in developing countries has long focused on public rather than private capital. Emphasizing the collective target of " $0.7 \%$ of GNP in ODA" adopted by the UN $[18,19]$ in line with estimates on funds needed to address urgent development agendas, the development community sought to meet the funding gap in developing countries by expanding the scale of ODA. This position remained steady until the fall of the Berlin Wall, which formalized the end of the Cold War. Total ODA began to decline as a result of massive ODA cuts by the United States, which no longer needed to focus on national security and geopolitical strategies in response to the Cold War, as well as by Japan, which faced its own financial and economic difficulties [20].

Even after entering the twenty-first century, the international community stressed the need to increase ODA to donors through the Millennium Development Goals (MDGs) in 2000, the Monterrey Conference on Financing for Development in 2002, the Gleneagles G8 Summit and other fora in 2005. However, although ODA flows have doubled since the twentieth century [21], total ODA has not met the 0.7\% ODA/GNI (Gross National Income) target. As a result, the international community began searching for other financial resources beyond ODA to address this development financing gap. Among potential sources, private capital flows to developing countries, which have been increasing since the mid-1970s, have come to the fore. Accordingly, the expansion of private investment for development purposes is being touted within the development community with initiatives such as "from billions to trillions" and the "Roadmap for Financing the 2030 Agenda for Sustainable Development" presented by multilateral development banks (MDBs) and the United Nations (UN), respectively. When it comes to private investment, the international community frequently uses the terms "mobilizing," "leveraging" and "catalyzing" [22] These three terms, which are used interchangeably, are based on expanding private investment in developing countries to realize the broader development agenda by using traditional development finance sources as catalysts to overcome barriers to investment, such as higher risk and low returns $[3,16,23]$.

In this regard, blended finance (which covers impact, returns and leverage) is attracting significant attention [6]. In particular, OECD DAC (Development Assistance Committee) member countries and development finance institutions (DFIs), primarily responsible for contributing to sustainable development in developing countries, are eager to utilize blended finance to expand private investment. Accordingly, on the basis of "Blended Finance for Unlocking Commercial Finance for the SDGs" adopted at the OECD DAC High 
Level Meeting in 2017, the development community aims to transform fully market-based financing in support of sustainable development by using ODA as a catalyzing force.

However, while it is clear that inflows of private capital into developing countries are being activated with support by the development community, prospects may not be as bright as they seem. This is because the scale or speed of private capital flows through blended finance not only lags the total annual ODA, but it also falls short of the estimated financing gap for developing countries to achieve the SDGs. Just as importantly, there are differences in private capital flows depending on a country's economic level, with Convergence [9] highlighting that the flow of private resources toward least-developed countries (LDCs) is relatively low vis-à-vis developing countries with larger economies. This phenomenon demonstrates the existence of the Lucas Paradox, or the observation that capital does not flow from rich to poor countries but is mostly invested in rich countries. In other words, the Lucas Paradox runs counter to a core objective of development finance, which is to secure funds for countries most in need. The following section explores the Lucas Paradox in depth, particularly as it relates to prospects for blended finance.

\subsection{Implications of the Lucas Paradox in Blended Finance}

In terms of neoclassical economic theory, investments should occur in poorer economies if they are allowed to move freely, and this should continue to be true until investment returns are equalized in all countries [24-26]. However, Robert Lucas observed that evidence from reality stood contrary to what would be prescribed by neoclassical economic theory, wherein private capital did not actually flow into developing countries when comparing the state of capital inflows in the United States versus India. This "Lucas Paradox" is still witnessed in the capital flows of today's free economic system [10,11], with data showing that private investment in developing countries is not active compared to investment in capital markets of developed economies with the highest level of per capita income $[4,12]$.

As expanding private capital flows is necessary to stimulate economic growth in developing countries, empirical studies have attempted to identify reasons why neoclassical theory diverges from economic reality. Prior studies have identified determinants such as capital market imperfections [27-30], information asymmetries [31,32], lack of financial development [33-36] and sovereign risk [37,38], with recent studies explaining the Lucas Paradox in light of institutional quality [26,39-42]. Studies have then prescribed ways to expand private investment toward developing countries based on the results of applying this determinant to FDI and portfolio equity investment.

As such, the presence of the Lucas Paradox in the free economic market has resulted in proposals to boost private investment towards developing countries based on the findings of research dealing with determinants of the paradox. However, while blended finance is not immune to this phenomenon, it has been promoted by the development community without considering the paradox's implications. For private capital to continue to flow into developing countries in line with heightened expectations by the development community, it is necessary to analyze blended finance approaches that take the effects of the Lucas Paradox into consideration. Furthermore, empirical analysis that considers the paradox is even more urgent, as official development funds are being used as catalysts to boost flows of private capital. This is because official development funds, which have long faced limitations in scaling up, should not be used indiscriminately.

Accordingly, this paper aims to adjust blended finance strategy to activate private capital flows towards developing countries through an empirical review of the use of traditional development funds as catalysts in consideration of the Lucas Paradox. Specifically, it investigates whether and how the effects of the Lucas Paradox can be mitigated in blended finance approaches, as this would contribute to invigorating private capital flows towards developing countries. To this end, this paper aims to diagnose the Lucas Paradox in recipient countries that are obligated to apply a blended finance approach, as well as to analyze determinants that will be the basis for proposing measures to mitigate the paradox's effects. As noted earlier, there are no previous studies (according to the authors' 
knowledge) that apply the Lucas Paradox to recipient countries eligible to receive ODA to diagnose the paradox and empirically review determinants. As such, this study would provide the first diagnosis of the Lucas Paradox for recipient countries under the support of OECD DAC, as the analysis focuses on blended finance approaches that strategically use official development finance to promote private capital flows.

As an initial framework, this paper will review the determinants of capital flows in recipient countries where a blended finance strategy is applied in light of the Lucas Paradox, from the perspective of recipient countries. The methodology and variables used by Alfaro et al. [25] and related literature form the basis for the investigation. Alfaro et al. [25] utilized cross-country OLS regressions based on data averaged between 1970 and 2000 from 98 countries to reveal what factors (determinants) in developing countries mitigate the Lucas Paradox. They adopted inflows of direct and portfolio equity investment per capita as a dependent variable and institutional quality, human capital and distantness as independent variables. In particular, the study captured the Lucas Paradox by fixing the GDP variable. Given the methodology's influence in diagnosing the Lucas Paradox and identifying determinants in consequent studies, this paper also reviews the paradox of recipient countries based on this methodology. In addition, total ODA is added as an independent variable to examine whether official development finance is a determinant of the Lucas Paradox. A more detailed review of the data and the methods utilized in this study are presented in the next section.

\section{Research Design}

This paper will investigate determinants of capital flows for a cross-sectional sample of 157 countries (see Table A1 in the Appendix A), including recipients and OECD DAC members, by broadly following the methodology employed by Alfaro et al. [25] and subsequent studies. Specifically, it will utilize aggregate capital inflow data averaged between 2002 and 2018. Capital flows reviewed in this paper are targeted at the sum of FDI and portfolio equity investment, which stimulates economic and social development in developing countries, grounded in the fact that private capital through a blended finance approach is mainly formed by traditional investment [9]. Building on these results, the direction of blended finance approaches considering the Lucas Paradox will be proposed.

While this paper broadly follows the framework provided by Alfaro et al. [25], it also reflects variables and methodologies advanced by subsequent studies. Instead of using panel data that vary across countries and time, this paper employs country-level averages from 2002 to 2018 . The reason for using averaged variables over time is that most variables used in this analysis are unlikely to change dramatically over time [25,43]. It is also aimed at reducing outliers and endogeneity, and above all, as mentioned by Alfaro et al. [25], average inflows can capture the long-run effects of various explanations of the Lucas Paradox. To avoid heteroscedasticity and serial correlation in $\varepsilon_{\mathrm{i}}$, we employ the Huber/White/sandwich cluster robust estimator.

By applying average-based variables, this paper is interested in understanding determinants of the Lucas Paradox in recipient countries, as blended finance approaches use official development funds as catalysts to secure private resources. As such, the country of interest in this study is the recipient country, or the target country of blended finance. To this end, we utilize the following (Equation (1)):

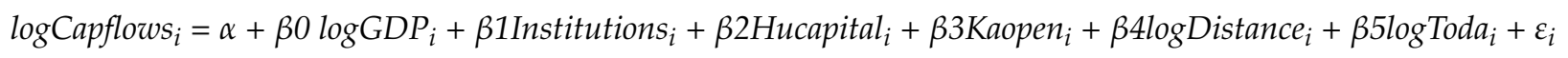

where $i$ represents variation across countries and $\alpha$ is a constant term. $\log$ Capflows is the $\log$ of average capital flows per capita per year, measured as the sum of foreign direct investment and portfolio equity flowing into a country in a particular year. In particular, the natural logs are taken to suppress outliers and endogeneity [26,44,45]. $\log G D P$ represents real gross domestic product per capita in the base year (2002), which is fixed to capture the Lucas Paradox. Institutions refers to institutional quality, Hucapital refers to human capital and $\log$ Distance refers to asymmetric information, which are based on the methodology 
employed by Alfaro et al. [25]. Kaopen indicates restriction to capital mobility, which borrows the openness variables suggested by relevant studies [25,45]. In addition, $\log T o d a$ refers to total ODA value, which is a unique variable added in this paper. Finally, $\varepsilon$ refers to the error term. Data descriptions and sources can be found in Table A2 of the Appendix A.

Institutional quality (Institutions), which Alfaro et al. [25] cited as the main determinant of the Lucas Paradox, comes from the World Bank's worldwide governance indicators (WGI) developed by Kaufmann et al. [46]. Although Alfaro et al. [25] used PRS Group's International Country Risk Guide as an institutional quality variable, data from WGI are utilized in this paper to review the level of institutional quality for a greater number of countries. Since WGI data developed by Kauffmann et al. [46] are constructed based on a wide range of cross-country surveys and polls by experts and use an unobserved components model, we find these data to be more appropriate to review institutional quality in this analysis. Indicators can be categorized into six broad groups, each of which represents a different aspect of institutional quality in a country: (1) voice and accountability; (2) political stability and absence of violence; (3) government effectiveness; (4) regulatory quality; (5) control of corruption; (6) rule of law. Scores for these indicators range between -2.5 and +2.5 , with higher scores indicating better governance.

Human capital variables (Hucapital) are taken from the Penn World Table version 9.1 [47], with the average value from 2002 to 2018 being used in the analysis. The index is based on years of education and educational returns by country. To review restrictions to capital mobility (Kaopen), or financial openness, this study uses Kaopen data developed by Chinn and Ito [48], as several studies following that of Alfaro et al. [25] have utilized Kaopen data to capture capital movement restrictions in the Lucas Paradox [44,49]. Kaopen is based on binary dummy variables that codify the tabulation of restrictions on cross-border financial transactions reported in the IMF's Annual Report on Exchange Arrangements and Exchange Restrictions. In particular, Kaopen is indexed with the following four variables: (K1) the presence of multiple exchange rates; (K2) restrictions on current account transactions; (K3) restrictions on capital account transactions; (K4) the requirement of the surrender of export proceeds. This extracted Kaopen is scaled between -2.5 and 2.5, with higher values indicating larger degrees of financial openness. As a proxy for restriction to capital mobility that Alfaro et al. [25] attempted to measure, this paper also uses the average of Kaopen data between 2002 and 2018.

Distance variables (logDistance) are used to see how international capital market failures, mainly asymmetric information, respond to the Lucas Paradox. Alfaro et al. [25] used the variable "Distinctness," which considers GDP-weighted distances of all partner countries from a particular country, noting that academic circles consider distance as a proxy for asymmetric information. Following this logic, this paper examines the effect of asymmetric information of private capital flows in recipient countries by using the distance variable. Data on bilateral distances between main cities of a particular country and main cities of other countries come from the Centre d'Etudes Prospectives et d'Informations Internationales (CEPII). These data, developed by Mayer and Zignago [50], cover different measures of bilateral distances (in kilometers) available for most countries across the world. Distance data extracted from CEPII are then calculated as an average after the weight of GDP is reflected. While it is not a direct measure for distance, as it uses GDP shares as weights, a relatively small economy of two equally distant countries represents a higher value [39]. These extracted data are expressed in natural logarithm.

Finally, the ODA variable $(\log T o d a)$ is the average of total ODA provided by donors to each recipient country between 2002 and 2018. This paper is the first to adopt and review ODA as a variable with the aim of analyzing the response relationship between blended finance approaches and the Lucas Paradox. ODA data for the variable in this study are extracted from CRS of the OECD, with ODA data consisting of the sum of flows to countries and territories on the DAC list of ODA recipients and to multilateral development institutions. In particular, these data are constructed from information provided by official agencies (including state and local governments) or by executing agencies, with the main 
objective of use being the promotion of economic development and welfare of developing countries. In addition, it is only counted as ODA if it is concessional and a grant element of at least $25 \%$ is guaranteed. To review the response of the Lucas Paradox to actual ODA use, ODA data are extracted for gross disbursements. The data in current U.S. dollars are deflated by the U.S. CPI (consumer price index) with base year $2010=100$ and divided by the midyear population. This average value is applied with natural logarithm.

\section{Key Findings and Discussion}

\subsection{Confirmation of the Lucas Paradox}

Prior to the regression analysis, which examines determinants of the Lucas Paradox on private flows in recipient countries, it is necessary to confirm whether the Lucas Paradox still exists when it comes to capital flows around the world. Alfaro et al. [25] confirmed a strong presence of the Lucas Paradox by comparing capital inflows to rich and poor countries for the period between 1970 and 2000. Following this methodology, we analyze capital flows between 2000 and 2018, as shown in Figure 1. In addition, while Alfaro et al. [25] classified countries into developed and developing, this paper distinguished between the 29 OECD DAC member countries and 133 developing countries, as the focus of this study is the development of developing countries. Private flows are then calculated as an average over five years, with findings showing a stark difference between the two categories and supporting the existence of the Lucas Paradox.

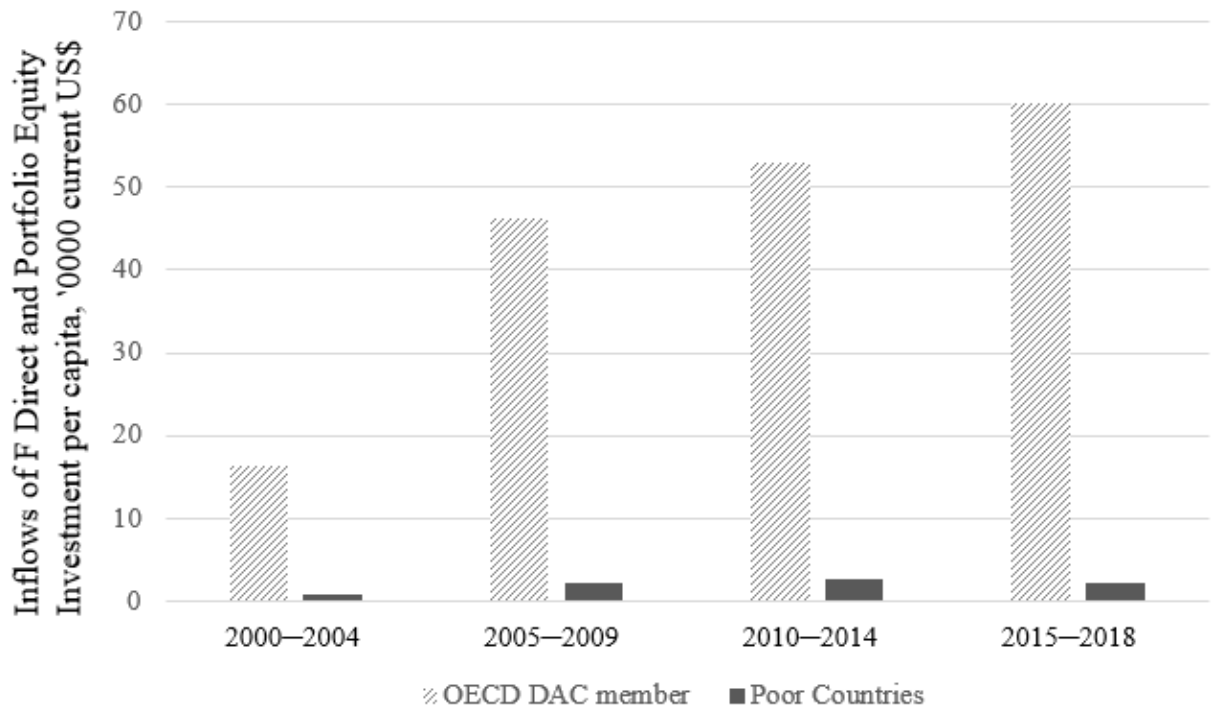

Figure 1. Total equity inflows per capita to OECD DAC members and developing countries, 2000-2018. Inflows of total FDI and portfolio equity investment divided by population are based on the IMF's Balance of Payments database and World Bank's IDS in current U.S. dollars. Data are for 162 countries and averaged over five-year periods. FDI inflows, which include equity capital, reinvestment of earnings and other capital, represent cross-border investments associated with a resident in one economy having control or a significant degree of influence on the management of an enterprise that is a resident in another economy. Portfolio equity investment inflows include equity securities other than those recorded as direct investment, including shares, stocks, depository receipts and direct purchases of shares in local stock markets by foreign investors. OECD DAC members include 29 countries that ensure economic and political capacities to deliver development cooperation programs, representing richer countries; poor countries denote the 133 remaining ones that are classified as "poor" by the World Bank and OECD.

Capital inflows to OECD DAC members (representing developed countries) have been higher than those of developing countries, with the difference widening more sharply since 2005. For developing countries, the increase in capital inflows is not only modest but in fact slightly decreased from 2015. On the other hand, capital inflows to OECD DAC 
member countries sharply rose in 2005, steadily increasing until 2018. Capital inflows from developed countries between 2015 and 2018 were about 20 times higher than those from developing countries, with results confirming that the Lucas Paradox still exists in real capital flows and has even become stronger.

To see if the Lucas Paradox exists among developing countries of varying economic levels, we examined capital inflows between 2000 and 2018 by dividing developing countries into UMICs (upper middle-income countries), LMICs (lower middle-income countries) and LDCs (least developed countries). Based on our analysis (see Figure 2), private capital inflows to UMICs (which have the highest economic level among developing countries) have been more active than those with lower economic levels, increasingly sharply since 2005. While LMICs and LDCs had similar inflows around 2000, the Lucas Paradox began to become apparent between the two categories in 2005. Through this, we find that the Lucas Paradox does not only exist in the developed-developing country dichotomy, but this is also the case when it comes to private flows for different economic tiers within developing economies.

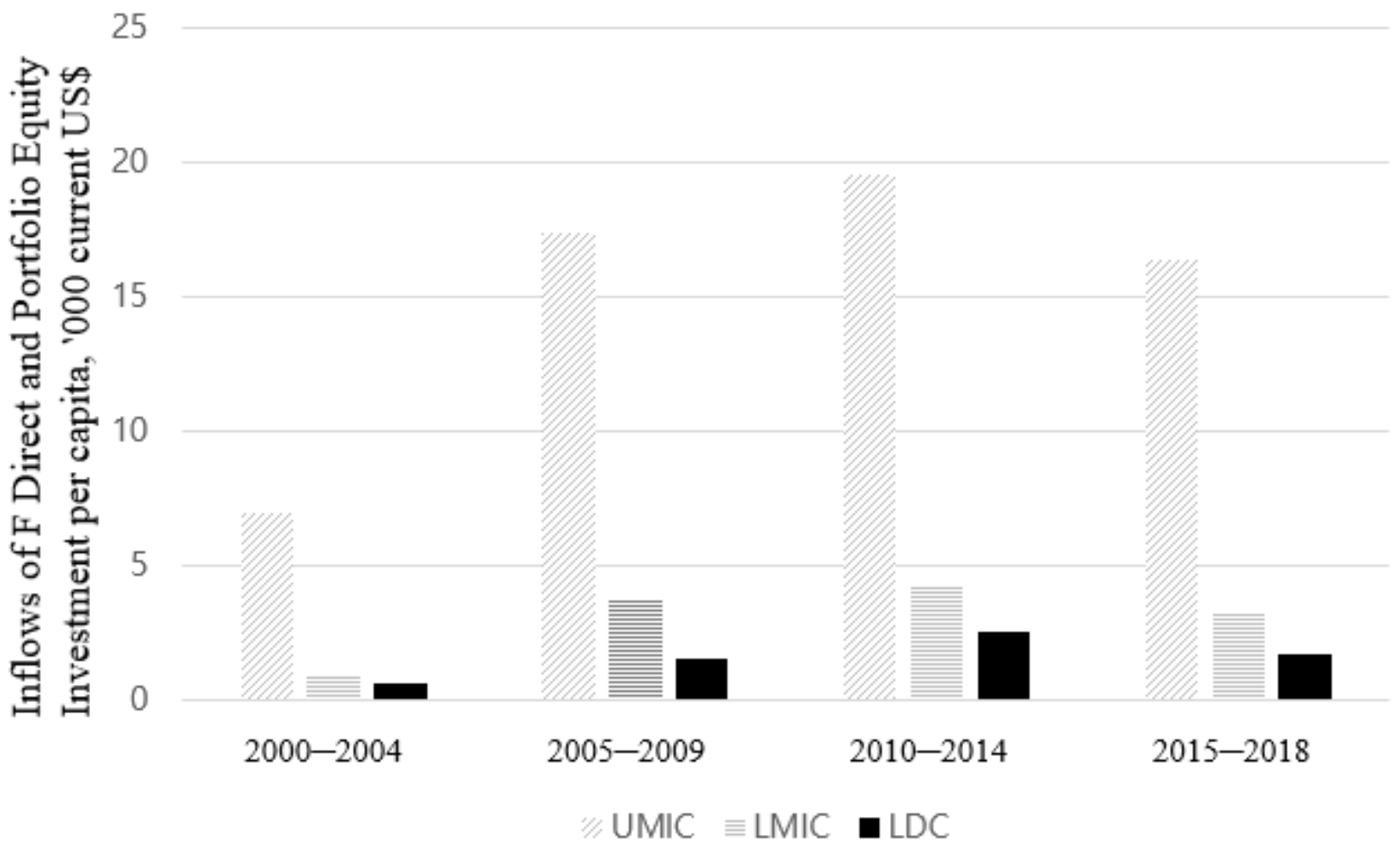

Figure 2. Total equity inflows per capita to developing countries by income level, 2000-2018. Inflows of total FDI and portfolio equity investment divided by population are based on the IMF's Balance of Payments database and World Bank's IDS in current U.S. dollars. Data are for 133 developing countries (excluding Democratic People's Republic of Korea and Zimbabwe) and averaged over five-year periods. FDI inflows, which include equity capital, reinvestment of earnings and other capital, represent cross-border investments associated with a resident in one economy having control or a significant degree of influence on the management of an enterprise that is resident in another economy. Portfolio equity investment inflows include equity securities other than those recorded as direct investment, including shares, stocks, depository receipts and direct purchases of shares in local stock markets by foreign investors. UMICs include 51 countries, defined as those with a GNI per capita between USD 3956 and 12,235 in 2016 (excluding Helena, Saint Lucia, Saint Vincent and the Grenadines and Wallis and Futuna). LMICs include 37 countries (per capita GNI USD 1006-3955 in 2016), excluding Tokelau. LDCs denote 47 remaining countries classified as those with a GNI per capita of less than USD 1005 in 2016 (excluding Eritrea) from 2010 to 2018. 


\subsection{Descriptive Statistics}

As the Lucas Paradox is strongly rooted in private capital flows toward recipient countries, this reinforces the need to examine determinants of the paradox in light of blended finance approaches. Based on our analytical framework in the previous section, we first provide descriptive statistics, as shown in Table 1. Capital inflows per capita expressed in natural logarithm (dependent variable) averaged 4.96, which is equivalent to USD 3227. The country, inter alia, with the least capital inflows from abroad is -USD 22 (Suriname), while the highest is USD 393,041 (Luxembourg). The standard deviation between each data in the capital inflows is 1.88. If we look at descriptive statistics on capital inflows for recipient countries eligible to receive ODA, the average per capita is about USD 173, of which the highest capital flow is USD 1673 (Antigua and Barbuda).

Table 1. Descriptive summary statistics.

\begin{tabular}{cccccc}
\hline & Obs. & Mean & Std. Dev. & Min. & Max. \\
\hline $\log$ Capflows & 155 & 4.96 & 1.88 & 0.49 & 12.80 \\
$\operatorname{logGDP}$ & 157 & 7.71 & 1.56 & 4.91 & 11.00 \\
Institutions & 155 & -0.09 & 0.86 & -1.59 & 1.84 \\
Hucapital & 122 & 2.45 & 0.70 & 1.16 & 3.67 \\
Kaopen & 147 & 0.25 & 1.53 & -1.92 & 2.33 \\
$\log$ Distance & 155 & 9.00 & 0.18 & 8.78 & 9.49 \\
logToda & 119 & 3.82 & 1.40 & -0.95 & 7.54 \\
\hline
\end{tabular}

For the GDP, the average expressed in natural logarithm is 7.71, indicating that the average per capita is about USD 7643. When examining descriptive statistics on GDP for recipient countries eligible to receive ODA, the average per capita is USD 1923. The recipient, inter alia, with the lowest GDP is USD 135 (Ethiopia), while the country with the highest GDP is USD 12,612 (Antigua and Barbuda). As of 2018, the World Bank designates countries with a per capita income of USD 3895 or less as low-income and lower-middle income countries. According to this designation, more than one-half of the countries considered in this analysis are classified as lower-middle income countries.

For institutional quality, which Alfaro et al. [25] found to be the main determinant of the Lucas Paradox, the average in this study is -0.09 , and the standard deviation between countries is 0.86 . As previously mentioned, worldwide governance indicators from the World Bank were used to review the response of the paradox to institutional quality and cover six dimensions of governance: (1) voice and accountability; (2) political stability and absence of violence; (3) government effectiveness; (4) regulatory quality; (5) control of corruption; (6) rule of law. The indicator is presented by evaluating institutional aspects of each country with a score between -2.5 and 2.5. A lower score indicates low institutional quality, whereas a higher score indicates a higher level. Between 2002 and 2018 , the average score of indicators for the country with the lowest institutional quality is -1.59 (Afghanistan), while the highest is 1.84 (Finland).

Under the assumption that a lack of human capital accumulation is a determinant of the Lucas Paradox, the variable on human capital consists of a proxy for years of schooling and returns on education. Among 157 countries, the average of 122 countries (where data were able to be obtained) is 2.45 , and the standard deviation is 0.7 . A higher score indicates a higher level of accumulated human capital in a country. Among countries covered in this study, Burkina Faso (1.16) has the lowest level of human capital, while the United States and the United Kingdom (3.67) have the highest levels.

In terms of restrictions on capital movements, the average of countries covered in this study based on Kaopen data, which measure the degree of capital account openness, is 0.25, and the standard deviation is 1.53. As Kaopen presents levels of capital movement between a range of -2.5 and 2.5 , the average level of capital movement in recipient countries is low, and the gap between countries is also expected to be large. Among them, Myanmar (1.92) 
is the country with the strictest capital mobility restrictions, while the majority of the freest are OECD DAC members (2.33), including some recipient countries.

The average of the distance index expressed in the natural logarithm, a proxy for asymmetric information, is nine, which is about $8330 \mathrm{~km}$. A higher value represents higher remoteness and information friction, while a lower value is expected to have the opposite effect. Among the countries covered in this study, countries considered to have the lowest exposure to asymmetric information are Albania, Bosnia and Herzegovina, Bulgaria, Greece, Hungary, Italy, North Macedonia and Slovenia, while the country with the highest level of exposure is Tonga. Finally, the average of total ODA expressed in the natural logarithm is 3.82 , which is around USD 114 . The country receiving the lowest ODA support is Thailand (-USD 1.65), while the highest is Tuvalu (USD 1894).

\subsection{Regression Results}

The regression analysis based on these data is shown below.

Based on the methodology and variables provided by Alfaro et al. [25] and subsequent studies, this analysis also examines changes in each variable by fixing the GDP variable to capture the Lucas Paradox. Furthermore, the response of the Lucas Paradox is reviewed in a multiple regression framework. Similar to results suggested by previous studies on determinants of the Lucas Paradox, our findings suggest that the paradox also exists in recipient countries eligible to receive ODA. Column one of Table 2 shows that there are restrictions on private capital inflows to recipient countries due to the influence of the Lucas Paradox. By capturing the paradox as GDP variables based on the fact that the Lucas Paradox exists in recipient countries, it is statistically significant at the $1 \%$ level that countries with higher economic levels have higher inflows of private capital.

Table 2. Lucas Paradox in recipient countries and OECD DAC member countries.

\begin{tabular}{|c|c|c|c|c|c|c|c|}
\hline \multicolumn{8}{|c|}{ Average of the Log of Capital Inflows per Capita } \\
\hline & (1) & (2) & (3) & (4) & (5) & (6) & (7) \\
\hline \multirow[t]{2}{*}{$\log G D P$} & $1.009^{* * *}$ & $0.846^{* * *}$ & $0.829 * * *$ & $0.926^{* * *}$ & $1.001 * * *$ & $1.051 * * *$ & $0.661^{* * *}$ \\
\hline & $(0.0641)$ & $(0.106)$ & $(0.0949)$ & $(0.0660)$ & $(0.0634)$ & $(0.0745)$ & $(0.126)$ \\
\hline \multirow[t]{2}{*}{ institutions } & & $0.349 *$ & & & & & $0.601 * *$ \\
\hline & & $(0.194)$ & & & & & $(0.252)$ \\
\hline \multirow[t]{2}{*}{ hucapital } & & & $0.506^{* * *}$ & & & & $0.667^{* * *}$ \\
\hline & & & $(0.166)$ & & & & $(0.202)$ \\
\hline \multirow[t]{2}{*}{ kaopen } & & & & 0.0579 & & & -0.00818 \\
\hline & & & & $(0.0669)$ & & & $(0.0709)$ \\
\hline \multirow[t]{2}{*}{ logDistance } & & & & & $-0.912 * *$ & & 0.524 \\
\hline & & & & & $(0.405)$ & & $(0.504)$ \\
\hline \multirow[t]{2}{*}{$\log T o d a$} & & & & & & 0.0600 & $0.189 * *$ \\
\hline & & & & & & $(0.0630)$ & $(0.0840)$ \\
\hline \multirow[t]{2}{*}{ Constant } & $-2.824^{* * *}$ & -1.540 * & $-2.689 * * *$ & $-2.206^{* * *}$ & 5.453 & $-3.340 * * *$ & -6.960 \\
\hline & $(0.490)$ & $(0.833)$ & $(0.530)$ & (0.517) & (3.598) & $(0.584)$ & $(4.442)$ \\
\hline Observations & 155 & 153 & 121 & 145 & 153 & 117 & 81 \\
\hline $\mathrm{R}$-squared & 0.716 & 0.721 & 0.753 & 0.728 & 0.722 & 0.572 & 0.656 \\
\hline
\end{tabular}

Note: Dependent variable is average capital (foreign direct and portfolio equity) inflows per capital. Heteroscedasticity robust standard errors are in parentheses. ${ }^{* * *} p<0.01,{ }^{* *} p<0.05$ and ${ }^{*} p<0.1$ denote significance at $1 \%, 5 \%$ and $10 \%$, respectively.

Institutional quality, the main variable that explains the Lucas Paradox in the study by Alfaro et al. [25], is added to column two. Upon this addition, a change occurs in private capital inflows affected by GDP, but unlike the findings by Alfaro et al. [25], the Lucas Paradox does not disappear in our study. Although institutional quality is significant at the $10 \%$ level, GDP is still more significant at the $1 \%$ level. This supports empirical studies [26,44-46] that suggest Alfaro et al.'s [25] methodology does not take the natural logarithm of dependent variables and that institutional quality expressed in natural logarithms does not fully explain the mitigation of the Lucas Paradox. 
However, this study, which focused on the recipient countries eligible to receive ODA, shows that although the paradox does not disappear, mitigation of the Lucas Paradox is statistically more significant in terms of human capital and distance variables, which include the influence of asymmetric information, than institutional quality. As shown in column three, human capital is presented with an explanatory power of $75.3 \%$, which is statistically significant at the $1 \%$ level. Moreover, the addition of the distance variable in column five, without considering additional factors, is given a negative value at the $5 \%$ level, suggesting that countries with close distances between countries (that is, countries that are less subject to asymmetric information constraints) can increase inflows of private capital.

However, our findings find that the total ODA variable does not affect private capital flows. Column six, with the addition of the total ODA variable, shows the existence of the Lucas Paradox at the $1 \%$ level with an explanatory power of $57.2 \%$. Although the Lucas Paradox does not disappear, it shows that total ODA, along with the quality of institutions and human capital, has statistical significance. This suggests that, in order to expand inflows of private capital into developing countries (particularly for ODA recipients), the use of ODA in a catalytic role needs to be adjusted considering institutional quality and human capital.

In addition to these results, we conducted a multicollinearity review of the variables used in the analysis. In general, a variance inflation factor (VIF) value above 10 indicates high correlation (i.e., multicollinearity) and is cause for concern. As shown in Table 3, no variables with a VIF over 10 exist. As the mean value of the VIF is 1.54, there is a slight correlation between the given explanatory variable and other explanatory variables in the model. However, it appears that the mean value is not severe enough to require attention as it is close to one, suggesting no correlation at all. Thus, the above regression analysis finds the absence of a multicollinearity problem.

Table 3. Multicollinearity review of equation variables.

\begin{tabular}{ccc}
\hline Variable & VIF & 1/VIF \\
\hline logGDP & 2.23 & 0.449035 \\
Hucapital & 1.68 & 0.594446 \\
Institutions & 1.53 & 0.651891 \\
logToda & 1.39 & 0.719453 \\
logDistance & 1.24 & 0.805603 \\
Kaopen & 1.19 & 0.841747 \\
Mean VIF & 1.54 & \\
\hline
\end{tabular}

To diagnose the Lucas Paradox one step further, we conducted a regression analysis by dividing recipients into three groups (LDCs, LMICs and UMICs) according to the DAC list of ODA recipients. First, the regression results for LDCs are as follows.

The OECD classified countries whose GNI per capital is below USD 1005 as LDCs (as of 2016) in the list of ODA recipients applied in 2018 and 2019. Based on these criteria, the number of LDCs reviewed in this study is 43 . Column one of Table 4 shows that LDCs are affected by the Lucas Paradox, as are countries in the group at different income levels. However, the presence of the Lucas Paradox among LDCs does not seem as strong when compared with results of the entire recipient country (column one of Table 2), as the Lucas Paradox is statistically significant with $12.3 \%$ explanatory power at the 5\% level. Institutional quality variables eliminate the paradox, while the quality of institutions is not statistically significant. This is the same for human capital and distance variables, which are statistically more significant than institutional quality for recipient countries. In addition, it appears that total ODA is unable to explain the paradox. While column seven of the multiple regression analysis indicates that total ODA is statistically significant at the $10 \%$ level and that the Lucas Paradox disappears, since it is of statistical significance as all other variables are added, the above regression alone is insufficient to suggest this 
with confidence. Further empirical analysis of other approaches, as well as a case review of variables adopted in multiple regression analyses, may help to provide further insight.

Table 4. Lucas Paradox in least developed countries.

\begin{tabular}{|c|c|c|c|c|c|c|c|}
\hline \multicolumn{8}{|c|}{ Average of the Log of Capital Inflows per Capita } \\
\hline & (1) & (2) & (3) & (4) & (5) & (6) & (7) \\
\hline \multirow[t]{2}{*}{$\log G D P$} & $0.682 * *$ & 0.597 & 0.563 & $0.657 *$ & $0.733 *$ & 0.535 & 0.205 \\
\hline & $(0.298)$ & $(0.365)$ & $(0.450)$ & $(0.369)$ & $(0.380)$ & $(0.434)$ & $(0.513)$ \\
\hline \multirow[t]{2}{*}{ institutions } & & 0.200 & & & & & 0.226 \\
\hline & & $(0.434)$ & & & & & $(0.777)$ \\
\hline \multirow{2}{*}{ hucapital } & & & 1.039 & & & & 1.055 \\
\hline & & & $(0.637)$ & & & & $(0.768)$ \\
\hline \multirow[t]{2}{*}{ kaopen } & & & & 0.157 & & & -0.0405 \\
\hline & & & & $(0.140)$ & & & $(0.142)$ \\
\hline \multirow[t]{2}{*}{$\log$ Distance } & & & & & -0.261 & & 2.844 \\
\hline & & & & & (1.464) & & $(2.556)$ \\
\hline \multirow[t]{2}{*}{$\log T o d a$} & & & & & & 0.143 & $0.944^{*}$ \\
\hline & & & & & & $(0.289)$ & $(0.480)$ \\
\hline \multirow[t]{2}{*}{ Constant } & -1.032 & -0.382 & -1.914 & -0.748 & 1.000 & -0.749 & -29.01 \\
\hline & $(1.811)$ & $(2.390)$ & $(2.817)$ & $(2.246)$ & (11.99) & $(2.014)$ & (22.91) \\
\hline Observations & 42 & 41 & 29 & 36 & 41 & 42 & 27 \\
\hline $\mathrm{R}$-squared & 0.123 & 0.128 & 0.139 & 0.155 & 0.124 & 0.130 & 0.335 \\
\hline
\end{tabular}

Note: Dependent variable is average capital (foreign direct and portfolio equity) inflows per capital. Heteroscedasticity robust standard errors are in parentheses. ${ }^{* *} p<0.05$ and ${ }^{*} p<0.1$ denote significance at $5 \%$ and $10 \%$, respectively.

Next, we performed a regression analysis on the Lucas Paradox for lower middleincome countries (LMICs). LMICs are defined as those countries with a GNI per capita between USD 1006 and 3955 (as of 2016), with the number of LIMCs in this study totaling 33. As shown in Table 5, column one shows that the Lucas Paradox also exists for LMICs. Interestingly, the results of LMICs were statistically significant at the $1 \%$ level in terms of institutional quality, human capital and total ODA variables. Thus, for LMICs, the quality of institutions appears to eliminate the Lucas Paradox, which is in line with findings by Alfaro et al. (2008).

Table 5. Lucas Paradox in lower middle-income countries.

\begin{tabular}{|c|c|c|c|c|c|c|c|}
\hline \multicolumn{8}{|c|}{ Average of the Log of Capital Inflows per Capita } \\
\hline & (1) & (2) & (3) & (4) & (5) & (6) & (7) \\
\hline $\log G D P$ & $\begin{array}{c}0.610^{* * *} \\
(0.191)\end{array}$ & $\begin{array}{c}0.294 \\
(0.216)\end{array}$ & $\begin{array}{c}0.682 * * * \\
(0.195)\end{array}$ & $\begin{array}{l}0.549 * \\
(0.270)\end{array}$ & $\begin{array}{c}0.630 \text { *** } \\
(0.183)\end{array}$ & $\begin{array}{c}0.472 * * * \\
(0.158)\end{array}$ & $\begin{array}{c}0.357 \\
(0.289)\end{array}$ \\
\hline institutions & & $\begin{array}{c}1.083^{* * * *} \\
(0.387)\end{array}$ & & & & & $\begin{array}{c}0.779 \\
(0.457)\end{array}$ \\
\hline hucapital & & & $\begin{array}{c}0.781^{* * *} \\
(0.239)\end{array}$ & & & & $\begin{array}{c}0.339 \\
(0.324)\end{array}$ \\
\hline kaopen & & & & $\begin{array}{c}0.130 \\
(0.122)\end{array}$ & & & $\begin{array}{r}-0.0102 \\
(0.122)\end{array}$ \\
\hline logDistance & & & & & $\begin{array}{c}-1.351 \text { ** } \\
(0.597)\end{array}$ & & $\begin{array}{l}0.0781 \\
(0.685)\end{array}$ \\
\hline $\log T o d a$ & & & & & & $\begin{array}{c}0.401 * * * \\
(0.111)\end{array}$ & $\begin{array}{c}0.324^{* *} \\
(0.118)\end{array}$ \\
\hline Constant & $\begin{array}{c}-0.0547 \\
(1.342)\end{array}$ & $\begin{array}{c}2.710 \\
(1.643)\end{array}$ & $\begin{array}{c}-2.418 \\
(1.717)\end{array}$ & $\begin{array}{c}0.371 \\
(1.909)\end{array}$ & $\begin{array}{l}11.97 * * \\
(5.289)\end{array}$ & $\begin{array}{l}-0.591 \\
(1.103)\end{array}$ & $\begin{array}{l}-0.573 \\
(7.620)\end{array}$ \\
\hline Observations & 33 & 33 & 29 & 32 & 33 & 32 & 27 \\
\hline R-squared & 0.156 & 0.365 & 0.305 & 0.173 & 0.217 & 0.394 & 0.485 \\
\hline
\end{tabular}

Note: Dependent variable is average capital (foreign direct and portfolio equity) inflows per capital. Heteroscedasticity robust standard errors are in parentheses. ${ }^{* * *} p<0.01,{ }^{* *} p<0.05$ and ${ }^{*} p<0.1$ denote significance at $1 \%, 5 \%$ and $10 \%$, respectively. 
In addition, while human capital is statistically significant for LMICs (similar to the results for all recipient countries), this does not make the Lucas Paradox disappear. Meanwhile, what is noteworthy are the results for the total ODA variable. Although the Lucas Paradox does not completely disappear, total ODA variables are explained as determinants of the paradox at the $1 \%$ level without the addition of other factors. This is not found in the regression results for LDCs or for all recipient countries. Furthermore, results of the multiple regression analysis in column seven show that institutional quality and total ODA make the Lucas Paradox disappear. Above all, it is shown that total ODA variables are statistically significant at a $5 \%$ level (unlike other variables).

Table 6 presents regression results for the 47 UMICs in this analysis, representing the highest income group in the DAC list of ODA recipients. Unlike LMICs, where institutional quality is described as a determinant of the Lucas Paradox, institutional quality does not make the paradox disappear in UMICs. In UMICs, total ODA does not affect the mitigation of the Lucas Paradox, which is the same in multiple regression analyses. However, it is statistically significant that institutional quality eliminates the Lucas Paradox at the 5\% level when supported by other variables in the multiple regression model.

Table 6. Lucas Paradox in upper middle-income countries.

\begin{tabular}{|c|c|c|c|c|c|c|c|}
\hline \multicolumn{8}{|c|}{ Average of the Log of Capital Inflows per Capita } \\
\hline & (1) & (2) & (3) & (4) & (5) & (6) & (7) \\
\hline $\log G D P$ & $\begin{array}{c}0.798^{* * *} \\
(0.233)\end{array}$ & $\begin{array}{c}0.651^{* *} \\
(0.271)\end{array}$ & $\begin{array}{c}0.794^{* *} \\
(0.345)\end{array}$ & $\begin{array}{c}0.766^{* * *} \\
(0.261)\end{array}$ & $\begin{array}{c}0.857^{* * * *} \\
(0.210)\end{array}$ & $\begin{array}{c}0.740 * * * \\
(0.242)\end{array}$ & $\begin{array}{c}0.502 \\
(0.297)\end{array}$ \\
\hline institutions & & $\begin{array}{c}0.287 \\
(0.316)\end{array}$ & & & & & $\begin{array}{c}0.797^{* *} \\
(0.323)\end{array}$ \\
\hline hucapital & & & $\begin{array}{c}0.186 \\
(0.545)\end{array}$ & & & & $\begin{array}{c}0.212 \\
(0.575)\end{array}$ \\
\hline kaopen & & & & $\begin{array}{l}0.0109 \\
(0.103)\end{array}$ & & & $\begin{array}{c}-0.0427 \\
(0.117)\end{array}$ \\
\hline logDistance & & & & & $\begin{array}{c}-1.102 \\
(0.663)\end{array}$ & & $\begin{array}{c}0.320 \\
(0.793)\end{array}$ \\
\hline $\log T o d a$ & & & & & & $\begin{array}{c}0.0792 \\
(0.0732)\end{array}$ & $\begin{array}{c}0.102 \\
(0.0920)\end{array}$ \\
\hline Constant & $\begin{array}{l}-0.919 \\
(1.920)\end{array}$ & $\begin{array}{c}0.315 \\
(2.231)\end{array}$ & $\begin{array}{l}-1.536 \\
(2.742)\end{array}$ & $\begin{array}{l}-0.667 \\
(2.132)\end{array}$ & $\begin{array}{c}8.628 \\
(6.448)\end{array}$ & $\begin{array}{l}-0.711 \\
(1.962)\end{array}$ & $\begin{array}{l}-2.280 \\
(7.087)\end{array}$ \\
\hline Observations & 46 & 46 & 29 & 45 & 46 & 44 & 28 \\
\hline $\mathrm{R}$-squared & 0.253 & 0.276 & 0.181 & 0.224 & 0.302 & 0.267 & 0.475 \\
\hline
\end{tabular}

Note: ${ }^{* * *} p<0.01,{ }^{* *} p<0.05$.

As such, this paper finds that differences exist in the determining factors of the Lucas Paradox according to income level among recipient countries. Similar to the results of the analysis of all recipient countries, in all three groups (LDCs, LMICs and UMICs), while institutional quality and human capital differed to varying degrees, it is found that they have some influence on the mitigation of the paradox. We also found that the response of the paradox in LMICs stands out. Unlike other groups, institutional quality among LMICs makes the Lucas Paradox disappear. Moreover, total ODA appeared to be a variable that could explain mitigation of the paradox. Although total ODA is shown as a factor explaining mitigation of the Lucas Paradox, if other variables are guaranteed in LDCs, it is not as clear as the results for LMICs. Overall, the mitigation of the Lucas Paradox seems to be well explained in LMICs. On this basis, the Lucas Paradox is stronger when income levels are lower or higher. 
In sum, this paper serves as the first diagnosis in the academic literature of the Lucas Paradox from the perspective of recipient countries eligible to receive ODA. In addition, the dependent variable (private capital flows) is expressed in a natural logarithm, reflecting previous criticism of the methodology employed by Alfaro et al. [25]. Based on this analysis, we find that institutional quality (Institutions) does not sufficiently explain the Lucas Paradox for recipient countries eligible to receive ODA.

On the other hand, human capital (Hucapital) and distance (logDistance) have statistical significance at the $1 \%$ and $5 \%$ levels as determinants of the Lucas Paradox, respectively, although they do not completely eliminate its effects. Meanwhile, multiple regression analysis of all recipients reveals that total ODA (logToda) explains the Lucas Paradox. In LMICs, the Lucas Paradox is relatively flexible. In particular, the paradox does not completely disappear in LMICs, but total ODA shows statistical significance as a determinant of the paradox at the $1 \%$ level. On the other hand, in LDCs where the blended finance approach needs to be applied first, each variable (without considering additional factors) failed to explain the paradox, while a multiple regression analysis found that total ODA (logToda) has statistical significance at the $10 \%$ level in mitigating the Lucas Paradox, while also causing the paradox to disappear.

\subsection{Limitations of the Study}

This paper is significant in that it identifies determinants of capital flows in recipient countries where a blended finance strategy is applied in light of the Lucas Paradox. Specifically, results differ depending on the income level of the recipient countries. In particular, the approach proposed by this study may contribute to policy recommendations within the development community that look to expand the flow of private resources through blended finance to achieve the broader development agenda. At the same time, we recognize a few limitations with regards to this analysis. First, the dependent variable adopted for the regression analysis is FDI and portfolio equity investments. While blended finance targets the flow of private capital to meet development goals in developing countries, demonstrable data on private capital used for development goals are not only vague, but this is also part of active discussion under the OECD DAC. While this study utilizes the FDI and portfolio equity investment data, as blended finance approaches mainly take place in traditional investment rather than impact investment with a development target (Convergence 2019), there may be a need for further analysis using data that emphasize the achievement of the SDGs in developing countries. As such, future research can supplement findings in this study by analyzing data on private capital flows that have a more explicit emphasis on intervention in a development context.

The second limitation is that of statistical analysis. The regression analysis, which provides a conclusion on the effect of independent variables on dependent variables, can only provide a partial picture at best and also remains a prediction of statistical significance. In addition, variables may also be biased or distorted. While this paper followed the convention of using averages in place of panel data with regards to institutional quality and capital flows [25,43], further research may further test potential endogeneity issues among variables. Going forward, qualitative research can help generate meaningful and feasible proposals in light of the empirical results, thus aiding in the effort to use public development funds as well as catalysts for securing private financial resources according to the core blended finance strategy. 


\section{Conclusions}

In this study, we found that the Lucas Paradox strongly exists in all recipient countries that can utilize ODA as a catalyst, which is the core of the blended finance strategy. Institutional quality, human capital and asymmetric information improvement appear to mitigate the Lucas Paradox, but the existence of the paradox nevertheless does not disappear entirely. In addition, total ODA, as well as institutional and human capital, appear to be determinants of the paradox in the multiple regression model, but they do not make the paradox completely disappear.

Based on these results, this paper confirms that there are differences in the Lucas Paradox within recipient countries and further analyzed determinants of the paradox by categorizing recipients according to income level (LDCs, LMICs and UMICs). Results reveal that the Lucas Paradox in LMICs is more flexible (i.e., works less strongly) than in other regions. In particular, institutional quality appeared to be the determinant of the Lucas Paradox in LMICs. In addition, while human capital and total ODA did not eliminate the paradox, they turned out to be determinants. Through multiple regression analysis, institutional quality and total ODA fully explained the Lucas Paradox. In other words, if ODA is guaranteed to recipient countries with high institutional quality, the low economic level of developing countries is not an obstacle to the flow of private capital. On the other hand, analysis for lower (LDCs) or higher (UMICs) income levels indicates that other variables have limited explanatory power in explaining the paradox.

First, LDCs are more lukewarm to the existence of the Lucas Paradox and the action of determinants compared to other regions. It is noteworthy, however, that when the regression analysis of total ODA is performed without consideration of other factors, not only are ODA variables and the Lucas Paradox insignificant, but only total ODA is the determinant of the paradox in the multiple regression model. Meanwhile, the Lucas Paradox is stronger in UMICs than in other regions. The distance variable, a proxy for asymmetric information, is shown to be a determinant, but it does not eliminate the paradox. However, with all explanatory variables considered in the multiple regression framework, institutional quality is found to fully explain the Lucas Paradox. As such, determinants of the Lucas Paradox differ according to income levels within recipient countries eligible to receive ODA.

Author Contributions: Conceptualization, H.K. and H.J.; methodology, H.K. and H.J.; validation, validation, H.K. and H.J.; formal analysis, H.K.; data curation, H.K.; writing-original draft preparation, H.K.; writing-review and editing, H.J.; visualization, H.K.; supervision, H.J. All authors have read and agreed to the published version of the manuscript.

Funding: This research received no external funding.

Institutional Review Board Statement: Not applicable.

Informed Consent Statement: Not applicable.

Data Availability Statement: Data available upon request.

Conflicts of Interest: The authors declare no conflict of interest. 


\section{Appendix A}

Table A1. Country Sample by Income Group.

\begin{tabular}{|c|c|c|c|}
\hline \multicolumn{4}{|c|}{ Countries Sample by Income Group (157) } \\
\hline OECD DAC Member & Upper Middle-Income & Lower Middle-Income & Least Developed Countries \\
\hline Countries (34) & Countries (UMICs) (46) & Countries (LMICs) (33) & $(\mathrm{LDCs})(43)$ \\
\hline “Australia (AUS) & “Albania (ALB) & “Armenia (ARM) & “Afghanistan (AFG) \\
\hline Austria (AUT) & Algeria (DZA) & Bolivia (BOL) & Angola (AGO) \\
\hline Belgium (BEL) & Antigua and Barbuda (ATG) & Cabo Verde (CPV) & Bangladesh (BGD) \\
\hline Bulgaria (BGR) & Argentina (ARG) & Cameroon (CMR) & Benin $(\mathrm{BEN})$ \\
\hline Canada (CAN) & Azerbaijan (AZE) & Congo (COG) & Bhutan (BTN) \\
\hline Czech Republic (CZE) & Belarus (BLR) & Côte d'Ivoire (CIV) & Burkina Faso (BFA) \\
\hline Denmark (DNK) & Belize (BLZ) & Egypt (EGY) & Burundi (BDI) \\
\hline Finland (FIN) & Bosnia and Herzegovina (BIH) & El Salvador (SLV) & Cambodia (KHM) \\
\hline France (FRA) & Botswana (BWA) & Eswatini (SWZ) & Chad (TCD) \\
\hline Germany (DEU) & Brazil (BRA) & Georgia (GEO) & Comoros (COM) \\
\hline Greece (GRC) & China $(\mathrm{CHN})$ & Ghana (GHA) & Democratic Republic of the \\
\hline Hungary (HUN) & Colombia (COL) & Guatemala (GTM) & Congo $(\mathrm{COD})$ \\
\hline Iceland (ISL) & Costa Rica (CRI) & Honduras (HND) & Djibouti (DJI) \\
\hline Ireland (IRL) & Dominica (DMA) & India (IND) & Eritrea (ERI) \\
\hline Italy (ITA) & Dominican Republic (DOM) & Indonesia (IDN) & Ethiopia (ETH) \\
\hline Japan (JPN) & Ecuador (ECU) & Jordan (JOR) & Gambia (GMB) \\
\hline Korea, Rep. (KOR) & Equatorial Guinea (GNQ) & Kenya (KEN) & Guinea-Bissau (GNB) \\
\hline Kuwait (KWT) & Fiji (FJI) & Kyrgyzstan (KGZ) & Guinea (GIN) \\
\hline Luxembourg (LUX) & Gabon (GAB) & Moldova (MDA) & Haiti (HTI) \\
\hline Netherlands (NLD) & Grenada (GRD) & Mongolia (MNG) & Kiribati (KIR) \\
\hline New Zealand (NZL) & Guyana (GUY) & Morocco (MAR) & Lao People's Democratic \\
\hline Norway (NOR) & Iran (IRN) & Nicaragua (NIC) & Republic (LAO) \\
\hline Poland (POL) & Jamaica (JAM) & Nigeria (NGA) & Lesotho (LSO) \\
\hline Portugal (PRT) & Kazakhstan (KAZ) & Pakistan (PAK) & Liberia (LBR) \\
\hline Qatar (QAT) & Lebanon (LBN) & Papua New Guinea (PNG) & Madagascar (MDG) \\
\hline Romania (ROU) & Malaysia (MYS) & Philippines (PHL) & Malawi (MWI) \\
\hline Slovak Republic (SVK) & Maldives (MDV) & Sri Lanka (LKA) & Mali (MLI) \\
\hline Slovenia (SVN) & Marshall Islands (MHL) & Tajikistan (TJK) & Mauritania (MRT) \\
\hline Spain (ESP) & Mauritius (MUS) & Tunisia (TUN) & Mozambique (MOZ) \\
\hline Sweden (SWE) & Mexico (MEX) & Ukraine (UKR) & Myanmar (MMR) \\
\hline Switzerland (CHE) & Namibia (NAM) & Uzbekistan (UZB) & Nepal (NPL) \\
\hline United Arab Emirates (ARE) & North Macedonia (MKD) & Viet Nam (VNM) & Niger (NER) \\
\hline United Kingdom (GBR) & Palau (PLW) & Zimbabwe (ZWE)" & Rwanda (RWA) \\
\hline United States (USA)" & Panama (PAN) & & Sao Tome and Principe (STP) \\
\hline & Paraguay (PRY) & & Senegal (SEN) \\
\hline & Peru (PER) & & Sierra Leone (SLE) \\
\hline & Saint Lucia (LCA) & & Solomon Islands (SLB) \\
\hline & Saint Vincent and the & & Sudan (SDN) \\
\hline & Grenadines (VCT) & & Tanzania (TZA) \\
\hline & Samoa (WSM) & & Togo (TGO) \\
\hline & South Africa (ZAF) & & Tuvalu (TUV) \\
\hline & Suriname (SUR) & & Uganda (UGA) \\
\hline & Thailand (THA) & & Vanuatu (VUT) \\
\hline & Tonga (TON) & & Yemen (YEM) \\
\hline & Turkey (TUR) & & Zambia (ZMB)" \\
\hline & Turkmenistan (TKM) & & \\
\hline & Venezuela (VEN)"' & & \\
\hline
\end{tabular}

Note: Country data by income are extracted based on the DAC list of ODA recipients 2018-2019. Upper middleincome countries refer to countries with GNI per capita ranging from USD 3956 to USD 12,235 (as of 2016). Lower middle-income countries range from USD 1006 to USD 3955 (as of 2016). Least developed countries refer to countries with GNI per capita of less than USD 1005. 
Table A2. Data descriptions and sources.

\section{Dependent Variable}

1. $\log$ Capflows Inflows of capital per capita

(IMF), 2002-2018
USD
"Inflows of capital is sum of foreign direct and portfolio equity investment from IMF's International Financial Statistic database. The data in current U.S dollars are deflated by the U.S. Consumer Price Index with base year $2010=100$ taken from World Development Indicators (WDI), World Bank and divided by midyear population."

\section{Independent Variables}

2. $\log G D P \quad$ GDP per capita (World Bank), 2002
USD
"GDP per capita in 2002 is in current U.S. dollars from WDI, World Bank. It is deflated by the U.S. CPI with base year $2010=100$ (2002 US CPI = 82.5)."

"It is the average of the six World Governance Indicators (WGI) provided by the World Bank [46];

(voice and accountability, political stability, government effectiveness, regulatory quality, rule of law, and control of corruption. This indicator as an institutional quality proxy grades country from -2.5 (highly corrupt) to +2.5 (very clean)."
-2.5 weak to +2.5 strong
World Bank), 2002-2018

Human Capital (PWT 9.1), 2002-2018

Restriction to Capital Mobility

5. Kaopen
(Chinn and Ito database), 2002-2018 index

"The average of human capital index provided by Penn World Table 9.1 [47] is constructed from the data on years of schooling and returns to education."
"The average of Restriction to Capital Mobility is formed from the data kaopen [48] which indicates restriction to capital mobility. The kaopen index is scaled in the range between -2.5 and 2.5 , with lower values standing for larger degrees of restriction to capital mobility."

"The weighted average of the bilateral distances in kilometers available for country pairs across the world taken from GeoDist database of CEPII [50], using the GDP shares of the other countries as weights, average between 2002 and 2018."

Total ODA is constructed from the data on net ODA from OECD's CRS database. It is expressed in current U.S dollar, deflated by the U.S. CPI with $2010=100$ and divided by midyear population (2010) from WDI.

\section{References}

1. Bandura, R. Rethinking Private Capital for Development; CSIS Publishing: Washington, DC, USA, 2017.

2. UNCTAD. World Investment Report 2014: Investing in the SDGs: An Action Plan. United Nations Publication; UNCTAD: New York, NY, USA, 2014.

3. Küblböck, K.; Grohs, H. Blended Finance and its Potential for Development Cooperation; ÖFSE Briefing Paper, No. 21; Austrian Foundation for Development Research ÖFSE: Vienna, Austria, 2019.

4. OECD. Global Outlook on Financing for Sustainable Development 2019: Time to Face the Challenge; OECD Publishing: Paris, France, 2018.

5. Clark, R.; Reed, J.; Sunderland, T. Bridging Funding Gaps for Climate and Sustainable Development: Pitfalls, Progress and Potential of Private Finance. Land Use Policy 2018, 71, 335-346. [CrossRef]

6. WEF; OECD. Blended Finance Vol. 1: A Primer for Development Finance and Philanthropic Funders; World Economic Forum: Geneva, Switzerland, 2015.

7. OECD. Amounts Mobilised from the Private Sector for Development by Official Development Finance Interventions in 2018-2019; OECD Publishing: Paris, France, 2021.

8. OECD. Amounts Mobilised from the Private Sector by Development Finance Interventions in 2017-2018; OECD Publishing: Paris, France, 2020.

9. Convergence. The State of Blended Finance 2019; Convergence: Toronto, ON, Canada, 2019. 
10. Sheppard, R. Capital Markets Financing for Developing-Country Infrastructure Projects; DESA Discussion Pap. No. 28; United Nations: New York, NY, USA, 2003.

11. Broszkiewicz, M. Portfolio Investment Flows and the Lucas Paradox-An Evidence from the Global Economy in the 21st Century. Ekon. XXI Wieku 2017, 3, 91-105. [CrossRef]

12. OECD; UNCDF. Blended Finance in the Least Developed Countries 2019; OECD Publishing: Paris, France, 2019.

13. Hansen, H.; Rand, J. On the Causal Links between FDI and Growth in Developing Countries. World Econ. 2006, $29,21-41$. [CrossRef]

14. Lehnert, K.; Benmamoun, M.; Zhao, H. FDI Inflow and Human Development: Analysis of FDI's Impact on Host Countries' Social Welfare and Infrastructure. Thunderbird Int. Bus. Rev. 2013, 55, 285-298. [CrossRef]

15. Suehrer, J. The Future of FDI: Achieving the Sustainable Development Goals 2030 through Impact Investment. Glob. Policy 2019, 10, 413-415. [CrossRef]

16. Convergence. The State of Blended Finance 2018; Convergence: Toronto, ON, Canada, 2018.

17. Tew, R.; Caio, C.; Lonsdale, C. The Role of Blended Finance in the 2030 Agenda: Setting Out an Analytical Approach; Discussion Paper; Development Initiative: Bristol, UK, 2016.

18. World Council of Churches. Christian Concerns in Economic and Social Development. In Proceedings of the Minutes and Reports of the Eleventh Meeting of the Central Committee of the World Council of Churches, Geneva, Switzerland, 21-29 August 1958; Appendix XIV. p. 125.

19. Clemens, M.A.; Moss, T.J. The Ghost of 0.7 Per Cent: Origins and Relevance of the International Aid Target. Int. J. Dev. Issues 2007, 6, 3-25. [CrossRef]

20. Burnell, P. Foreign Aid Resurgent: New Spirit or Old Hangover? The United Nations University World Institute for Development Economics Research: Helsinki, Finland, 2004.

21. OECD. OECD DAC BF Principles for Unlocking Commercial Finance for the Sustainable Development Goals; OECD Publishing: Paris, France, 2017.

22. Pereira, J. Blended Finance: What It Is, How It Works and How It Is Used; Research Report: Oxfam, UK, 2017.

23. United Nations. Financing for Development: Progress and Prospects; Report of the Inter-Agency Task Force on Financing for Development; United Nations: New York, NY, USA, 2017.

24. Solow, R.M. A Contribution to the Theory of Economic Growth. Q. J. Econ. 1956, 70, 65-94. [CrossRef]

25. Alfaro, L.; Kalemli-Ozcan, S.; Volosovych, V. Why Doesn't Capital Flow from Rich to Poor Countries? An Empirical Investigation. Rev. Econ. Stat. 2008, 90, 347-368. [CrossRef]

26. Akhtaruzzaman, M.; Hajzler, C.; Owen, D. Does Institutional Quality Resolve the Lucas Paradox? Appl. Econ. 2018, 50, 455-474. [CrossRef]

27. Abiad, A.; Leigh, D.; Mody, A. Financial Integration, Capital Mobility, and Income Convergence. Econ. Policy 2009, 24, 241-305. [CrossRef]

28. Kalemli-Ozcan, S.; Reshef, A.; Sorensen, B.; Yosha, O. Why Does Capital Flow to Rich States? Rev. Econ. Stat. 2010, 92, 769-783. [CrossRef]

29. Reinhardt, D.; Ricci, L.A.; Tressel, T. International Capital Flows and Development: Financial Openness Matters. J. Int. Econ. 2013, 91, 235-251. [CrossRef]

30. Islamaj, E.; Kose, M.A. What types of capital flows help improve international risk sharing? J. Int. Money Finance 2021, $122,102544$. [CrossRef]

31. Portes, R.; Rey, H. The Determinants of Cross-Border Equity Flows. J. Int. Econ. 2005, 65, 269-296. [CrossRef]

32. Hashimoto, Y.; Wacker, K.M. The Role of Information for International Capital Flows: New Evidence from the SDDS. Rev. World Econ. 2016, 152, 529-557. [CrossRef]

33. Forbes, K. Why Do Foreigners Invest in the United States? J. Int. Econ. 2010, 80, 3-21. [CrossRef]

34. Von Hagen, J.; Zhang, H. Financial Development and the Patterns of International Capital Flows; CEPR Discussion Pap. No. DP7690; Elsevier: Amsterdam, The Netherlands, 2010.

35. Gourinchas, P.O.; Jeanne, O. Capital Flows to Developing Countries: The Allocation Puzzle. Rev. Econ. Stud. 2013, 80, 1484-1515. [CrossRef]

36. Abdouli, M.; Hammami, S. Economic Growth, Environment, FDI Inflows, and Financial Development in Middle East Countries: Fresh Evidence from Simultaneous Equation Models. J. Knowl. Econ. 2020, 11, 479-511. [CrossRef]

37. Reinhart, C.; Rogoff, K. Serial Default and the "Paradox" of Rich-to-Poor Capital Flows. Am. Econ. Rev. 2004, 94, 53-58. [CrossRef]

38. Carmen, M.R.; Kenneth, S.R.; Savastano, M. Debt Intolerance; NBER Working Paper. NBER: Washington, DC, USA, 2003 ; No. 9908.

39. Ndiweni, Z.L.; Bonga-Bonga, L. Capital Inflows and Economic Growth Nexus in Sub-Saharan Africa: Evidence on the Role of Institutions; MPRA: Munich, Germany, 2021.

40. Contractor, F.J.; Dangol, R.; Nuruzzaman, N.; Raghunath, S. How do country regulations and business environment impact foreign direct investment (FDI) inflows? Int. Bus. Rev. 2020, 29, 101640. [CrossRef]

41. Asamoah, L.A.; Mensah, E.K.; Bondzie, E.A. Trade openness, FDI and economic growth in sub-Saharan Africa: Do institutions matter? Transnatl. Corp. Rev. 2019, 11, 65-79. [CrossRef]

42. Ly, S.; Abubakar, Y.A.; Mitra, J. Foreign direct investment and entrepreneurship: Does the role of institutions matter? Int. Bus Rev. 2021, 30, 101774. 
43. Azémar, C.; Desbordes, R. Has the Lucas Paradox been Fully Explained? Econ. Lett. 2013, 121, 183-187. [CrossRef]

44. Olano, A.D.V. The Lucas Paradox in the Great Recession: Does the Type of Capital Matter? Econ. Bull. 2018, 38, $1052-1057$.

45. Kaufmann, D.; Kraay, A.; Mastruzzi, M. The Worldwide Governance Indicators: Methodology and Analytical Issues; World Bank-Policy Research Working Paper WPS 5430; Cambridge University Press: Cambridge, UK, 2010.

46. Feenstra, R.C.; Inklaar, R.; Timmer, M.P. The Next Generation of the Penn World Table. Am. Econ. Rev. 2015, 105, 3150-3182. [CrossRef]

47. Chinn, M.D.; Ito, H. What Matters for Financial Development? Capital Controls, Institutions, and Interactions. J. Dev. Econ. 2006, 81, 163-192. [CrossRef]

48. Gammoudi, M.; Cherif, M. Capital Account Openness, Political Institutions and FDI in the MENA Region: An Empirical Investigation; Economics Discussion Paper No. 2015-10; Kiel Institute for the World Economy: Kiel, Germany, 2015.

49. Mayer, T.; Zignago, S. Notes on CEPII's Distances Measures: The Geodist Database; CEPII Working Paper No. 2011-25; Elsevier: Amsterdam, The Netherlands, 2011.

50. Aluko, O.; Ibrahim, M. Does Institutional Quality Explain the Lucas Paradox? Evidence from Africa. Econ. Bull. 2019, 39, 1687-1693. 